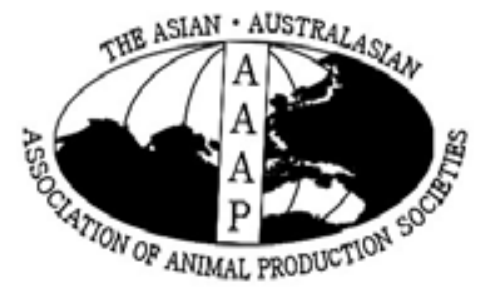

Asian-Aust. J. Anim. Sci.

Vol. 20, No. 3 : 405 - 411

March 2007

www.ajas.info

\title{
Effects of Gal-13 on the Content of Immunoglobulin, Proliferation of Lymphocyte and Antibody Titers after Vaccination with Infectious Bursal Disease Virus Vaccine in Chickens
}

\author{
Yang Yurong*, Jiang Yibao, She Ruiping ${ }^{1}$, Peng Kaisong ${ }^{1}$, Zhou Xuemei ${ }^{1}$, Yin Qingqiang \\ Wang Decheng ${ }^{1}$, Liu Tianlong ${ }^{1}$ and Bao Huihui ${ }^{1}$ \\ College of Animal and Veterinary Engineering, Henan Agricultural University, Zhengzhou 450002, P. R. China
}

\begin{abstract}
Gal-13 is an antimicrobial peptide isolated from chicken intestine. Ninety chickens were randomly divided into two groups (45 chickens for each group) to determine the effect of oral administration of Gal-13 on the acquired immune response. The chickens in the first group were fed a diet without Gal-13 as the control, and the chickens in the second group were fed the same diet, except that Gal-13 $(1 \mu \mathrm{g} / \mathrm{ml})$ was suspended in drinking water just after hatching. Samples of blood, thymus, bursa of fabricius and spleen were taken at day 1, 4, 7, 10 and 17. The chickens in both groups received infectious bursal disease virus vaccine at day 20, and then sera samples were collected for analysis at 14,21, 28 and 35 days after vaccination. The results showed: (1) Gal-13 could enhance the content of immunoglobulin $(\mathrm{Ig}) \mathrm{G}$ at the age of 4 to 10 days $(\mathrm{p}<0.05)$ and $\operatorname{IgM}$ at the age of 4 and 10 days $(\mathrm{p}<0.05)$ in the serum; (2) In vitro experiments showed that Gal-13 $(0.625-1.250 \mu \mathrm{g} / \mathrm{ml})$ enhanced the proliferation of peripheral blood lymphocytes of the chickens stimulated by lipopolysaccharide (LPS) and concanavlin A (ConA). Compared to the control, Gal-13 (1 $\mu \mathrm{g} / \mathrm{ml})$ enhanced the proliferation of bursa lymphocytes at 17 days of age $(p<0.01)$ and thymus lymphocytes at 7 days of age $(p<0.01)$, but restrained lymphocyte proliferation in chicken spleen and differed significantly at day 10 ( $p<0.01)$; (3) Gal-13 enhanced infectious bursal disease virus antibody in sera of chickens 21 days after infectious bursal disease virus vaccine administration $(\mathrm{p}<0.05)$. These results suggested that Gal-13 could modulate adaptive immune responses of chickens. (Key Words : Gal-13, Antimicrobial Peptides, Chicken, Intestine, Adaptive Immunity)
\end{abstract}

\section{INTRODUCTION}

For those animals living in an environment filled with potential pathogens daily, their ability to avoid infection depends on their innate and adaptive immunity. Components of microbial pathogens activate various recognition receptors on defence cells, resulting in the activation of numerous molecules and mediators of host defence including cytokines, acute phase proteins and antimicrobial peptides (Hancock and Scott, 2000). Antimicrobial peptides are polypeptides of fewer than 100 amino acids, they are found in all species of life, ranging from plants and insects to animals (Ganz, 2003; Wang et al., 2004). More than 880 such peptides have been discovered (http://www.bbcm.units.it/ tossi/pag5.htm). Antimicrobial

\footnotetext{
* Corresponding Author: Yang Yurong. Tel: +86-371-63558180, Fax: +86-371-63558180, E-mail: yangyu7712@sina.com ${ }^{1}$ China Agricultural University, Beijing 100094, P. R. China. Received March 6, 2006; Accepted June 6, 2006
}

peptides include defensins, cathelicidin, histatins, cathepsin $\mathrm{G}$, azurocidin, chymase, eosinophil derived neurotoxin, high mobility group 1 nuclear proteins, lactoferrin and many others. Based on the spacing pattern of cysteines, defensins are broadly divided into five groups, namely plant, invertebrate, $\alpha$-, $\beta$-, and $\theta$-defensins. The chicken genome encodes a total of 13 different $\beta$-defensins; these chicken $\beta$ defensin genes, designated as Gallinacin-1 Gallinacin-13, Gallinacin-13(Gal-13), are expressed in the colon and rectum of the chicken (Xiao et al., 2004).

Many studies have concentrated on the role of defensins in innate immunity, such as killing a broad spectrum of microbes including gram-negative and gram-positive bacilli, fungi and selected enveloped viruses. In addition to their antimicrobial activity, defensins have been reported to induce acquired host immunity (Oppenheim et al., 2003). Human neutrophil peptide (HNP) defensins can promote acquired systemic immune response (Lillard et al., 1999) through T-cell dependent cellular immunity and antigen- 
specific immunoglobulin production (Tani et al., 2000; Brogden et al., 2003). These observations suggest that defensins may play a role in the communication between innate and adaptive immunity. However, there are few studies of defensins on avian specific immunity. This study aimed to isolate Gal-13 from chicken intestine and evaluate the effect of Gal-13 on systemic immunity of chicken, and to provide a basic theory for the use of antimicrobial peptides.

\section{MATERIALS AND METHODS}

\section{Isolation of Gal-13 from chicken intestine}

Gal-13 was isolated from chicken intestine by acetic acid extraction (Ghosh et al., 2002). Chicken colon and rectum were washed with sterile physiological saline $(0.9 \%$ sodium chloride). The chorion and fat were removed and mucosa was isolated from the intestine. The mucosa was homogenized by Muller in ice-cold aqueous 5\% acetic acid $(1: 10 \mathrm{~W} / \mathrm{V})$ that contained $1 \mathrm{mmol} / \mathrm{L}$ protease inhibitor PMSF (Amresco, USA). The extracts were placed in a boiling water bath for $10 \mathrm{~min}$, then, following rapid cooling, the precipitate was discarded by centrifugation at 8,000 $\mathrm{r} / \mathrm{min}$ for $30 \mathrm{~min}$ at $4^{\circ} \mathrm{C}$. The clarified extracts were sonicated for $30 \mathrm{~s}$ on ice and stirred overnight at $4^{\circ} \mathrm{C}$. Icecold $5 \%$ acetic acid $(1: 1 \mathrm{~V} / \mathrm{V})$ was added in the presence of PMSF and extraction made overnight at $4^{\circ} \mathrm{C}$. The extract was centrifuged at $8,000 \mathrm{r} / \mathrm{min}$ for $30 \mathrm{~min}$ at $4^{\circ} \mathrm{C}$ and the $\mathrm{pH}$ of clarified extract was adjusted to 6.0 with sodium hydroxide. The precipitates that formed were removed by centrifugation $\left(8,000 \mathrm{r} / \mathrm{min}\right.$ for $30 \mathrm{~min}$ at $\left.4^{\circ} \mathrm{C}\right)$. Then the clarified extract was loaded on a $10 \times 300 \mathrm{~mm}$ Sephadex G100 column and eluted by $0.2 \mathrm{~mol} / \mathrm{L}$ sodium acetate buffer. Gal-13 elution was analyzed by agarose diffusion assay (Lehrer et al., 1991) and Pasteurella cuniculicida used as the test organism. The fractions of interest were purified with Tricine-PAGE (Schgger and Jagow, 1987) and subjected to $\mathrm{NH}_{2}$-terminal sequence determination by Edman degradation in the Institute of Process Engineering Chinese Academy of Sciences. Fractions of interest were collected and freeze-dried before storage at $0^{\circ} \mathrm{C}$ for future use.

\section{Animals and experimental treatments}

Ninety one-day-old healthy chickens (Lohmann Brown) were utilized in this experiment. These chickens had no previous history of Newcastle disease virus or infectious bursal disease virus as determined by agar plate agglutination. They were randomly assigned to two groups, each of 45 chickens. (1) The Gal-13 group(T): Gal-13 was suspended in drinking water at final concentration of $1 \mu \mathrm{g}$ $/ \mathrm{ml}$ and fed to chicks after hatching. (2) The control $\operatorname{group}(\mathrm{C})$ : the chickens were maintained without Gal-13.
Each group of chickens was housed in an individual cage. All chickens were not vaccinated, and the feed and water were given ad libitum.

\section{Sampling}

Five chickens from each group were randomly sampled at day 1, 4, 7, 10 and 17. Chickens were sacrificed, and then a blood sample was drawn into a heparinized tube and a blood clotting tube. Serum samples were aliquotted and stored at $-20^{\circ} \mathrm{C}$ until analysis. Thymus, bursa of fabricius and spleen were collected immediately under sterile conditions. Heparinized blood or immune organ samples were processed immediately for lymphocyte proliferation assays.

The chickens in both groups received infectious bursal disease virus vaccine (mid- virulence live vaccine , Beijing Academy of Agriculture and Forestry Science, P. R. China) at day 20, and then serum samples were collected for analysis at 14, 21, 28 and 35 days after vaccination.

\section{Immunological assays}

i) Measurement of the relative content of $\operatorname{IgG}, \operatorname{IgM}$ in sera was made by indirect ELISA test (Yang et al., 2005; Ahn et al., 2006).

ii) Measurement of lymphocyte proliferation by MTT method

Lymphocyte proliferation assay: $50 \mu \mathrm{l}$ ConA or LPS at the concentration of $40 \mu \mathrm{g} / \mathrm{ml}$ or $10 \mu \mathrm{g} / \mathrm{ml}$, diluted with RPMI 1640 supplemented with $4 \mathrm{mM}$ glutamine, $19 \mathrm{mM}$ HEPES, $100 \mathrm{U} / \mathrm{ml}$ penicillin and $100 \mu \mathrm{g} / \mathrm{ml}$ streptomycin, were placed in 96- well plates (tissue culture grade, flat bottom). Gal-13 was added to the first three wells at the concentration of $40 \mu \mathrm{g} / \mathrm{ml}$, then double dilutions made. Each plate had RPMI 1640 as blank, and various doses of Gal-13 had three replicates. Then $50 \mu \mathrm{l} 1.0 \times 10^{7} / \mathrm{ml}$ single lymphocyte cells prepared from peripheral blood obtained from control chickens were placed in 96-well plates in RPMI 1640 supplemented with 5\% FBS per well. After incubation (at $37^{\circ} \mathrm{C}, 5 \% \mathrm{CO}_{2}$ ) in a humidified atmosphere for $48 \mathrm{~h}, 10 \mu \mathrm{l}$ of the MTT $(5 \mathrm{mg} / \mathrm{ml})$ was added to each well. The microplates were incubated for $4 \mathrm{~h}$ in the humidified atmosphere, and $100 \mu$ of $10 \%$ SDS in $0.01 \mathrm{M}$ $\mathrm{HCl}$ solution added into each well. The plate was kept overnight in the incubator. Absorbance was recorded at 570 $\mathrm{nm}$ by ELISA plate reader (Thermo Electron Corporation, Waltham, USA) after the purple formazan crystals were solubilized. Each plate had RPMI 1640 as blank, and each sample had three replicates.

Measurement of the effect of Gal-13 on the proliferation of lymphocytes in vitro: $50 \mu \mathrm{l}$ Con A or LPS were placed in 96-well plates. Then $50 \mu \mathrm{l}$ of lymphocytes prepared from thymus, bursa or spleen obtained from both the Gal-13 
(a)

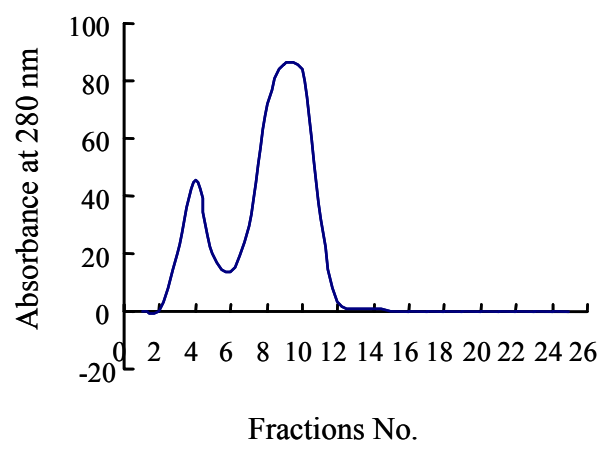

(b) 12

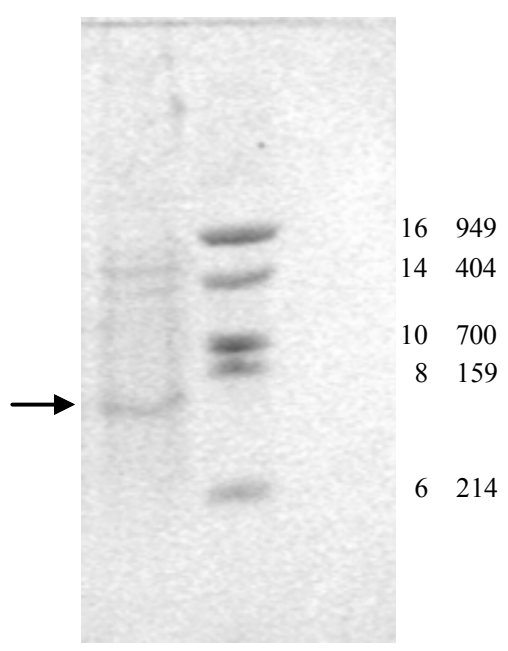

(c)

\begin{tabular}{ll}
\hline Molecular Weight by Tricine-PAGE & 7710 \\
\hline NH-terminal sequence & ARGFS... \\
\hline
\end{tabular}

Figure 1. (a) Sephadex G-100 gelatin separation of the extract from chicken colon mucosa. Bactericidal activity was present in the second peak. (b) Further purification of the second peak by Tricine-PAGE. Bactericidal activity was present in the third peak cingulum. (c) Molecular weight and NH-terminal sequence of Gal-13 purified from chicken colon mucosa.

Table 1. Amino acid sequence of Gal-13 (Gene ID: 414877; Pubmed accession numbers: AY621328.1, AAT48937)

\begin{tabular}{lll}
\hline Signal peptide & \multicolumn{1}{c}{ Propiece } & Mature peptide \\
\hline MRILQLLFAIVVILLLQDAP & ARGF & SDSQLCRNNHGHCRRLCFHMESWAGSCMNGRL \\
& & RCCRFSTKQPFSNPKHSVLHTAEQDPSP SLGGT \\
\hline
\end{tabular}

The intervening region between signal and mature peptide sequence is the short propiece.

Gal-13 is composed of total 89 amino acids.

group $(\mathrm{T})$ and the control group $(\mathrm{C})$ chickens were placed in 96-well plates in RPMI 1640 supplemented with 5\% FBS per well. As in the above protocol each plate had RPMI 1640 as blank and each sample had three replicates.

iii) Measurement of the infectious bursal disease virus antibody in sera by indirect ELISA test

ELISA plates, coated with $150 \mu$ infectious bursal disease virus (made in China Institute of Veterinary Drug Control, P. R. China) per well in sodium carbonate buffer (pH 9.6), were incubated overnight at $4^{\circ} \mathrm{C}$. Then, the plates were washed three times with PBS. The sera of chickens after injection with infectious bursal disease virus vaccine were collected at 14, 21, 28 and 35 days after vaccination, diluted 100-fold in PBS, and then $150 \mu$ diluted serum was placed in each well and incubated at $37^{\circ} \mathrm{C}$ for $2 \mathrm{~h}$. After washing three times, $150 \mu \mathrm{l}$ HRP rabbit anti-chicken IgG antibody (Military Medicine Academy Sciences of Liberation Army, P. R. China), diluted 800-fold in PBS, was added and then the plates were incubated at $37^{\circ} \mathrm{C}$ for $2 \mathrm{~h}$. Afterwards, plates were washed with PBS. $100 \mu$ OPDhydrogen peroxide was added to each well, then the plates were incubated at $37^{\circ} \mathrm{C}$ without light. Twenty minutes later, the reaction was stopped by adding $50 \mu \mathrm{l} 1 \mathrm{M} \mathrm{H}_{2} \mathrm{SO}_{4}$ to each well. The OD values were read at $492 \mathrm{~nm}$ by ELISA plate reader. Each plate had blank, negative and positive controls, and each sample had three replicates.

\section{Statistical analysis}

Experimental data were analyzed by one-way ANOVA using the SAS (Copyright (c) 1999-2001 by SAS Institute Inc., Cary, NC, USA.) statistical program. The results were expressed as the means and standard errors. Differences due to diet treatment were considered significant at $\mathrm{p}<0.05$ or $\mathrm{p}<0.01$.

\section{RESULTS}

\section{Isolation and characterization of Gal-13}

Gal-13 was extracted by acetic acid and purified by Sephadex G-100 gelatin and Tricine-PAGE. The second peak and the third cingulum had antibacterial activity after purification. Electrophoresis cingulums were electroblotted onto PVDF and analysed for $\mathrm{NH}_{2}$-terminal sequence. Gal13 appears as propiece and mature peptide when extracted from intestine (Figure 1). Chicken intestine yielded Gal-13 
$\operatorname{IgG}$

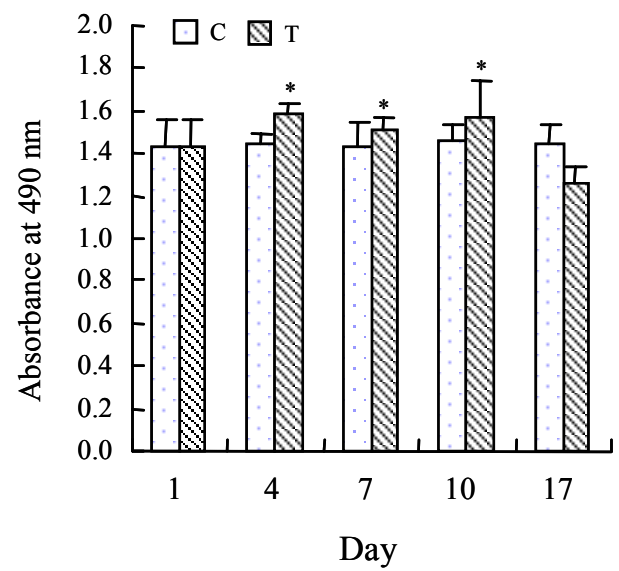

$\operatorname{IgM}$

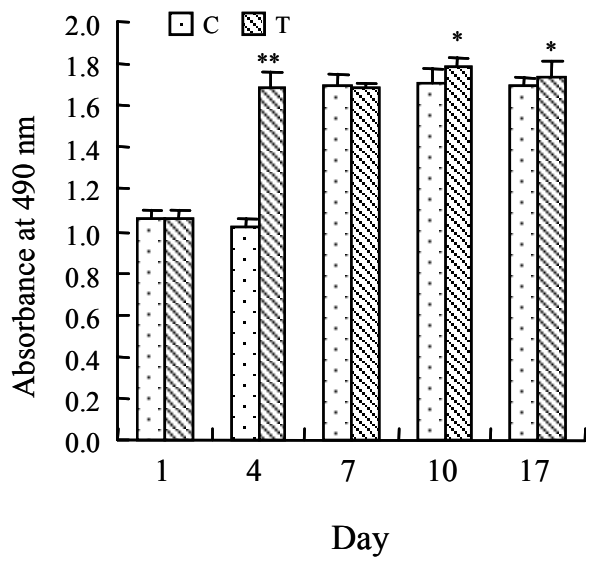

Figure 2. Immunoglobulin content of serum in chickens. With single "*”, significantly differ from control at $p<0.05$. With double "*”, significantly differ from control at $\mathrm{p}<0.01$. C: control group; T: Gal-13 group.

Table 2. Lymphocyte proliferation in peripheral blood by mitogen stimulation (Absorbance at $570 \mathrm{~nm}$ )

\begin{tabular}{lcccccc}
\hline & \multicolumn{5}{c}{ Gal-13 $(\mu \mathrm{g} / \mathrm{ml})$} \\
\cline { 2 - 7 } & 0 & 0.625 & 1.25 & 2.5 & 5 & 10 \\
\hline LPS & $0.45 \pm 0.06 \mathrm{Bc}$ & $0.90 \pm 0.11 \mathrm{Aa}$ & $0.94 \pm 0.13 \mathrm{Aa}$ & $0.62 \pm 0.09 \mathrm{Bb}$ & $0.23 \pm 0.04 \mathrm{Cd}$ & $0.12 \pm 0.04 \mathrm{Cd}$ \\
Con A & $0.36 \pm 0.06 \mathrm{Cc}$ & $1.06 \pm 0.13 \mathrm{Aa}$ & $1.15 \pm 0.20 \mathrm{Aa}$ & $0.71 \pm 0.08 \mathrm{Bb}$ & $0.15 \pm 0.05 \mathrm{Cd}$ & $0.11 \pm 0.03 \mathrm{Cd}$ \\
\hline
\end{tabular}

Lymphocytes from normal chicken were incubated with $20 \mu \mathrm{g} / \mathrm{ml}$ of Con A or $5 \mu \mathrm{g} / \mathrm{ml} \mathrm{LPS} \mathrm{along} \mathrm{with} \mathrm{various} \mathrm{concentrations} \mathrm{of} \mathrm{Gal-13.} \mathrm{After} 48 \mathrm{~h}$, proliferation was measured by MTT assays, results were compared with $0 \mu \mathrm{g} / \mathrm{ml}$ of Gal-13.

The values with different small letter, significantly differ from control at $\mathrm{p}<0.05$.

The values with different capital letter, significantly differ from control at $\mathrm{p}<0.01$.

which corresponded with the published findings (Table 1).

\section{Effect of Gal-13 on the content of immunoglobulin in serum of chickens}

The content of IgG in serum of the Gal-13 group chickens was enhanced at the age of 4 to 10 days compared with the control $(\mathrm{p}<0.05)$. The content of IgM had the same response as $\operatorname{IgG}$ at the age of $4(\mathrm{p}<0.01), 10$ and 17 days $(p<0.05)$ (Figure 2).

\section{Effect of Gal -13 on the lymphocyte proliferation of chickens}

Low doses of Gal-13 $(0.625-1.250 \mu \mathrm{g} / \mathrm{ml})$ promoted the proliferation of peripheral blood lymphocyte of chickens stimulated by LPS and Con A, compared with the control $(\mathrm{p}<0.01)$, but high doses of Gal-13 $(5 \mu \mathrm{g}-10 \mu \mathrm{g} / \mathrm{ml})$ restrained the proliferation of peripheral blood lymphocyte $(\mathrm{p}<0.01)$ (Table 2).

Gal-13 $(1 \mu \mathrm{g} / \mathrm{ml})$ enhanced the proliferation of lymphocytes in central immune organs of chickens. Compared to the control, Gal-13 promoted the proliferation of LPS-stimulated lymphocytes in bursa at 10-17 days of age and differed significantly at 17 days $(p<0.01)$ and enhanced the proliferation of Con A-stimulated lymphocytes in thymus at 4-17 days of age and differed significantly at 7 days $(p<0.01)$. Gal-13 restrained the proliferation of LPS or Con A-stimulated lymphocyte in chickens spleen at 4-10 days of age and differed significantly at 10 days $(\mathrm{p}<0.01)$ (Figure 3 ).

\section{Effect of Gal-13 on the level of infectious bursal disease virus $A b$ in sera}

Gal-13 enhanced the infectious bursal disease virus $\mathrm{Ab}$ in sera of chickens at 14 to 35 days after the chickens were injected with infectious bursal disease virus vaccine, but only differed significantly $(p<0.05)$ at 21 days compared with the control (Figure 4).

\section{DISCUSSION}

Defensins are antimicrobial proteins stored in the granules of neutrophils, and are produced by leucocytes and epithelial cells lining the environmental interface of the gastrointestinal, genitourinary tracts, tracheobronchial tree and skin(Shi et al., 1994; Oppenheim et al., 2003). Previous reports showed that defensins had chemotactic activity for immature dendritic cells and T cells (Yang et al., 1999). Defensins may play an important role in modulating the immune system. The immune response of central and peripheral immune organs plays an important role in the immunological defense against pathogens (Mingxing et al., 2005). The aim of this study was to assess the effect of Gal- 
Bursa lymphocyte proliferation

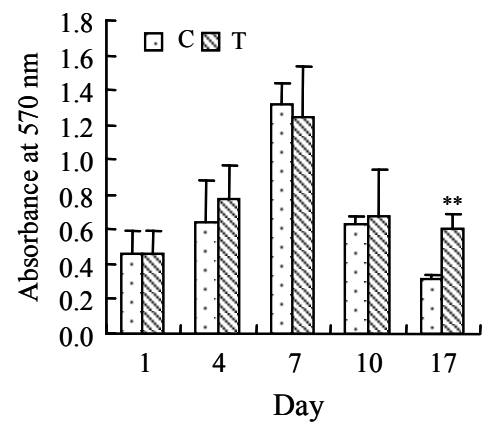

Spleen lymphocyte proliferation stimulated by Con A

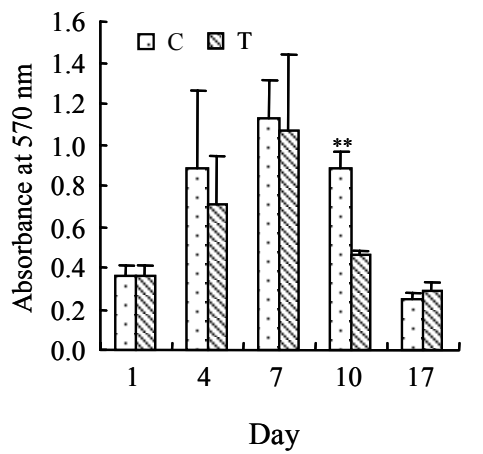

Thymus lymphocyte proliferation

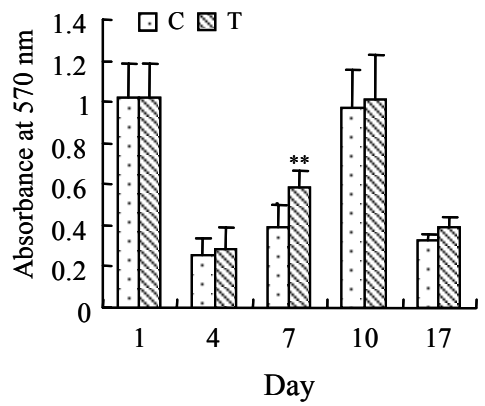

Spleen lymphocyte proliferation stimulated by LPS

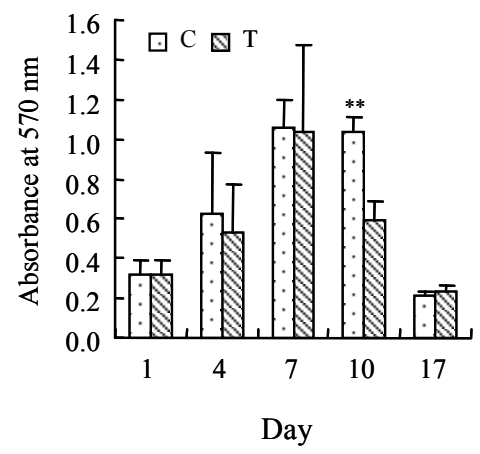

Figure 3. Lymphocyte proliferation in immune organs of chickens stimulated by mitogen. Lymphocytes from the chickens of control and Gal-13 groups were incubated with Con A or LPS; after $48 \mathrm{~h}$ proliferation was measured by MTT assays. With double “*”, significantly differ from control at $\mathrm{p}<0.01$. C: control group; T: Gal-13 group.

\section{Infectious Bursal Disease Virus antibody in} sera of chickens

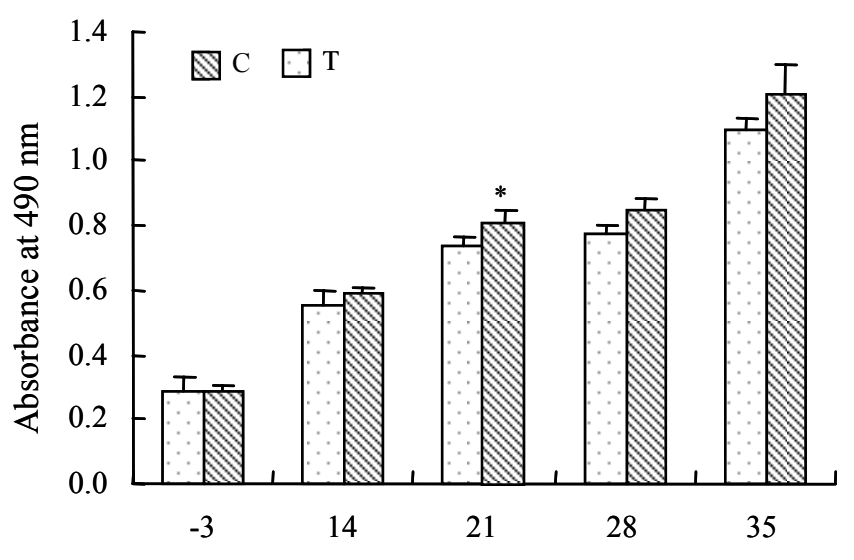

Days post-vaccination

Figure 4. Infectious Bursal Disease Virus antibody in sera of chickens. The chickens in both groups were injected with infectious bursal disease virus vaccine at 20 days of age, and sera samples were collected for analysis at 14, 21, 28 and 35 days after vaccination. Days: after injection with infectious bursal disease virus vaccine. With single “*”, significantly differ from control at $\mathrm{p}<0.05$. C: control group; T: Gal-13 group.

13 on systemic immunity of chicken.
The results of our study showed that Gal-13 could enhance the humoral and cellular immune responses of chickens after oral feeding with Gal-13. Compared with the control groups, Gal-13 enhanced the serum content of $\mathrm{IgG}$ from 4 to 10 days of age $(\mathrm{p}<0.05)$ and $\operatorname{IgM}$ from 10 to 17 days of age $(p<0.05)$. Gal-13 $(1 \mu \mathrm{g} / \mathrm{ml})$ also enhanced the proliferation of LPS-stimulated bursa lymphocytes at 17 days of age $(p<0.01)$ and Con A-stimulated thymus lymphocytes at 7 days of age $(p<0.01)$, but Gal-13 restrained the proliferation of LPS-stimulated and Con Astimulated spleen lymphocyte at 10 days of age $(p<0.01)$.

This study showed that Gal-13 up-regulated the immune response of central immune organs and down-regulated the immune response of peripheral immune organs. The reasons may be that bursa and thymus are central immune organs where immunocytes arise, differentiate and maturate, and spleen is a peripheral immune organ where antigen is captured and disposed; that also explains Gal-13 $(1 \mu \mathrm{g} / \mathrm{ml})$ as a harmless antigen which promotes the central immunocyte maturation.

There have been reports of defensin inducing cytotoxicity (Okrent, 1990; Lichtenstein, 1988). However, the injection of $1 \mu \mathrm{g}$ doses of human defensins into murine skin did not cause any effects indicative of toxicity or tissue damage such as swelling, redness and ulcer formation 
(Chertov, 1996). Our observations indicate that the concentrations of Gal-13 used in this study are not toxic for chickens. Partial breakdown of Gal-13 may occur by proteolysis in the digestive system, but this result also demonstrated that it could be effective by oral administration and determination of the biologically active concentration of Gal-13 requires more experimentation.

These results are partially consistent with those of others obtained in mammals. Lillard (1999) showed that HNP defensins plus OVA enhanced OVA-specific serum IgG antibody responses. HNP defensins promoted antigenspecific Ig production and cellular immunity. Tani (2000) reported that $1 \mu \mathrm{g} / \mathrm{ml}$ human defensins did not increase proliferation of LPS-stimulated spleen cells.

Our results showed that Gal-13 enhanced the infectious bursal disease virus $\mathrm{Ab}$ in sera of chickens 21 days after injection with infectious bursal disease vaccine $(p<0.05)$, compared with the control. Fritz (2004) also indicated that an artificial antimicrobial peptide could induce high levels of antigen-specific antibodies after co-injection of antimicrobial peptides with an available influenza vaccine.

Defensins serve as the signals in the course of innate defense which initiate, mobilize and amplify adaptive immune host defense. Defensins may cause subtle changes in epithelial cells; they may be absorbed rapidly by the mucosa and thus gain access to peripheral lymphoid tissues or dendritic cells to increase systemic immune responses (Yang et al., 1999; Biragyn et al., 2001; Yang et al., 2002), but the pathway of immunomodulation requires more experiments to confirm it.

Based on these results, Gal-13 is capable of promoting both humoral and cellular immune responses of central immune organs which could strengthen the viability of chickens. In addition to directly eradicating microorganisms, Gal-13 can be used as a signal to modulate adaptive immune responses.

\section{ACKNOWLEDGMENTS}

The authors thank National Natural Science Foundation of China (Grant No. 30471301) for financial support.

\section{ABBREVIATIONS}

ConA, Concanavalin A; LPS, Lipopolysaccharide; Ab, Antibody; Ig, Immunoglobulin; ELISA, Enzyme-linked Immunosorbent assay; PBS, Phosphate buffered saline; FBS, Fetal bovine serum; BSA, Bovine serum albumin;SDS, Sodium dodecyl sulfate; OVA, Ovalbumin; OD, Optical density; HNP, Human neutrophil peptide.

\section{REFERENCES}

Ahn, B. S., B. S. Jeon, E. G. Kwon, M. Ajmal Khan, H. S. Kim, J.
C. Ju and N. S. Kim. 2006. Estimation of Genetic Parameters for Daily Milk Yield, Somatic Cell Score, Milk Urea Nitrogen, Blood Glucose and Immunoglobulin in Holsteins. Asian-Aust. J. Anim. Sci. 19(9):1252- 1256.

Biragyn, A., M. Surenhu, D. Yang, P. A. Ruffini, B. A. Haines, E. Klyushnenkova, J. J. Oppenheim and L. W. Kwak. 2001. Mediators of innate immunity that target immature, but not mature, dendritic cells induce antitumor immunity when genetically fused with nonimmunogenic tumor antigens. J. Immunol. 167:6644-6653.

Brogden, K. A., M. Heidari, R. E. Sacco, D. Palmquist, J. M. Guthmiller, G. K. Johnson, H. P. Jia, B. F. Tack and P. B. McCray. 2003. Defensin-induced adaptive immunity in mice and its potential in preventing periodontal disease. Oral Microbiol. Immun. 18:95-99.

Chertov, O., D. F. Michiel, L. Xu, J. M. Wang, K. Tani, W. J. Murphy, D. L. Longo, D. D. Taub and J. J. Oppenheim. 1996. Identification of defensin-1, defensin-2, and CAP37 1azurocidin as T-cell chemoattractant proteins released from interleukin-8-stimulated neutrophils. J. Biol. Chem. 271:29352940.

Fritz, J. H., S. Brunner, M. L. Birnstiel, M. Buschle, A. V. Gabain, F. Mattner and W. Zauner. 2004. The artificial antimicrobial peptide KLKLLLLLKLK induces predominantly a TH2-type immune response to co-injected antigens. Vaccine. 22:32743284.

Ganz, T. Defensin: antimicrobial peptides of innate immunity. 2003. Nature rev. immunol. 3:710-720.

Ghosh, D., E. Porter, B. Shen, S. K. Lee, D. Wilk, J. Drazba, S. P. Yadav, J. W. Crabb, T. Ganz and C. L. Bevins. 2002. Paneth cell trypsin is the processing enzyme for human defensin-5. Nat Immunol. 3(6):583-590.

Hancock, R. E. W. and M. G. Scott. 2000. The role of antimicrobial peptides in animal defences. Proc. Natl. Acad. Sci. USA. 97:8856-8861.

Lehrer, R. I., M. Rosenman, S. S. Harwig, R. Jackson and P. Eisenhauer. 1991. Ultrasensitive assays for endogenous antimicrobial polypeptides. J. Immunol. Methods. 137(2):167173.

Lichtenstein, A. K., T. Ganz, T. M. Nguyen, M. E. Selsted and R. I. Lehrer. 1988. Mechanism of target cytolysis by peptide defensins. Target cell metabolic activities, possibly invoving endocytosis, are crucial for expression of cytotoxicity. J. Immunol. 140:2686-2694.

Lillard, J. W. J. R., P. N. Boyaka, O. Chertov, J. J. Oppenheim and J. R. Mcghee. 1999. Mechanisms for induction of acquired host immunity by neutrophil peptide defensins. Proc. Natl. Acad. Sci. 96:651-656.

Mingxing Ding, Zonghui Yuan, Yulian Wang, Huiling Zhu and Shengxian Fan. 2005. Effects of Olaquindox and Cyadox on Immunity of Piglets Orally Inoculated with Escherichia coli. Asian-Aust. J. Anim. Sci. 18(9):1320-1325.

Okrent, D. G., A. K. Lichtenstein and T. Ganz. 1990. Direct cytotoxicity of polymorphonuclear leukocyte granule proteins to human lung-derived cells and endothelial cells. Am. Rev. Respir Dis. 141:179-185.

Oppenheim, J. J., A. Biragyn, L. W. Kwak and D. Yang. 2003. Roles of antimicrobial peptides such as defensins in innate and adaptive immunity. Ann Rheum Dis. 62(90002): ii17-21. 
Schagger, H. and von Jagow G. 1987. Tricine-sodium dodecyl sulfate-polyacrylamide gel electrophoresis for the separation of proteins in the range from 1 to $100 \mathrm{kDa}$. Anal. Biochem. 166(2):368-379.

Shi, J. C., R. Ross, M. M. Chengappa and F. Blecha. 1994. Identification of a proline-arginine-rich antibacterial peptide from neutrophils that is analogous to PR-39, an antibacterial peptide from the small intestine. J. Leukocyte Biol. 56:807-811.

Tani, K. J., W. J. Murphy, O. Chertov, R. Salcedo, C. Y. Koh, I. Utsunomiya, S. Funakoshi, O. Asai, S. H. Herrmann, J. M. Wang, L. W. Kwak and J. J. Oppenheim. 2000. Defensins act as potent adjuvants that promote cellular and humoral immune responses in mice to a lymphoma idiotype and carrier antigens. Int. Immunol. 12(5):691-700.

Wang, Y. Z., Z. R. Xu, W. X. Lin, H. Q. Huang and Z. Q. Wang. 2004. Developmental Gene Expression of Antimicrobial Peptide PR-39 and Effect of Zinc Oxide on Gene Regulation of PR-39 in Piglets. Asian-Aust. J. Anim. Sci. 17(12):16351640 .
Xiao, Y. J., A. L. Hughes, J. Ando and Y. Matsuda. 2004. A genome-wide screen identifies a single $\beta$-defensin gene cluster in the chicken: implications for the origin and evolution of mammalian defensins. BMC Genomics 5:56-66.

Yang, D., A. Biragyn, L. W. Kwak and J. J. Oppenheim. 2002. Mammalian defensins in immunity: more than just microbicidal. Trends Immunol. 23(6):291-296.

Yang, D., O. Chertov, S. N. Bykovskaia, Q. Chen, M. J. Buffo, J. Shogan, M. Anderson, J. M. Schröder, J. M. Wang, O. M. Howard and J. J. Oppenheim. 1999. $\beta$-Defensins: linking innate and adaptive immunity through dendritic and $\mathrm{T}$ cell CCR6. Sci. 286(5439):525-528.

Yang, Y. R., S. M. Zheng, J. Liu and Y. B. Jiang. 2005. Dynamic changes of the relative content of immunoglobulins in local humor and immune organs index of chicks administrated with probiotics. Acta Veterinaria et Zootechnica Sinica (China). 36(4):352-356 